\title{
Judicial Dialogue in Human Rights Introductory Remarks
}

\author{
Elżbieta Karska \\ Ph.D., Professor of International Law, Head of Department of Human Rights \\ Protection and International Humanitarian Law, Faculty of Law and \\ Administration, Cardinal Stefan Wyszyński University in Warsaw, Poland \\ e.karska@uksw.edu.pl

\begin{abstract}
Karol Karski
Ph.D., Professor of International Law, Head of Department of Public

International Law, Faculty of Law and Administration, University of Warsaw, Poland

k.karski@wpia.uw.edu.pl
\end{abstract}

\begin{abstract}
The editors and other authors of the studies contained in this volume have chosen to focus attention on the problem of the broad concept of judicial dialogue, defined as the communication between various judicial authorities. The studies included consider the problem of institutional relations in the field of human rights protection from a national and international perspective. The issue of judicial dialogue in the field of human rights after the civil war in Rwanda is assessed. Next, the issue of the legal responsibility for placing hyperlinks in the context of the judicial dialogue between the European Court of Human Rights and the Court of Justice of the European Union in the field of protecting human rights on the internet is raised. Finally, the question of whether private or public legal entities can find direct protection under the InterAmerican System of Human Rights is analysed. The academic value of the analytical considerations presented in this volume is very high and this should lead to considerable readers' interest. This is because intellectual considerations of judicial dialogue in the field of human rights protection undoubtedly bring an interesting and significant new dimension not only to the theory but also to the practice of applying the law.
\end{abstract}




\section{Keywords}

judicial dialogue - human rights - international law - European Union law - case law

Since time immemorial, the characteristic of discussion, debate, conversation or dialogue has always been the feature intrinsically associated with the human experience, inseparably associated with the need for contact, relationships and the sharing of experiences. ${ }^{1}$ These terms can, therefore, apply to a range of human experience from dialogues between individuals, amongst various social groups or even between countries within the international community. ${ }^{2}$ Thus, a dialogue may be useful not just at a personal level, but also at the institutional level of modern societies. The same also applies to normative systems targeted at well-functioning justice systems, sensitive to the protection of human rights and the need to defend commonly accepted values. ${ }^{3}$ At a time of increased globalisation, examples of a judicial dialogue appear on the one hand inevitable and on the other highly desirable. One of the primary areas for the exchange of opinions concerns the rules and principles of human rights. ${ }^{4}$ The academic premise of this study is that it is significant that contemporary human rights law requires substantive world-wide dialogue, that takes into account diversity but seeks common denominators as a priority. Such a process may result in the increased effectiveness of the protection of human rights by establishing a universal matrix that can be generally respected.

Regardless of how abstract the idea is, the issue of the creation of a completely and uniformly understood and applied global system for the protection of human rights, respected by all nations, merits discussion. Furthermore, it must be appreciated that the drive to achieve this idea may have only positive effects in the form of continuous improvement in the level and interoperability

1 Petra Theunissen, Wan Norbani Wan Noordin, "Revisiting the concept 'dialogue' in public relations", 38/1 Public Relations Review (2012), pp. 5-13; Anna Wyrozumska, "The Central and Eastern European Judiciary and Transnational Judicial Dialogue on International Law", in A. Wyrozumska (ed.), Transnational Judicial Dialogue on International Law in Central and Eastern Europe (2017), pp. 15-18.

2 John Paul II, Dialogue for Peace: A Challenge for Our Time (1983), p. 6.

3 Milton Rokeach, "Introduction", in M. Rokeach (ed.), Understanding Human Values (1979), pp. 1-14; Shalom Schwartz, "Are there universal aspects in the structure and contents of human values?", 50/4 Journal of social issues (1994), pp. 19-45; Daniel Mayton, Sandra BallRokeach, William Loges, "Human values and social issues: An introduction", 50/4 Journal of Social Issues (1994), pp. 1-8.

4 Paolo Carozza, "Human dignity and judicial interpretation of human rights: A reply", 19/5 European Journal of International Law (2008), pp. 931-944. 
of agreed protection standards. It is very important for academic research to consider less popular concepts, which may nonetheless provide rational and practical solutions for many groups of beneficiaries but primarily for individuals. This issue of International Community Law Review concerns therefore highly important and topical issues of international law that concern above all judicial dialogue in the area of human rights and other equally important and current issues which, in terms of their subject, correlate with the mainstream of analytical studies presented here.

This issue starts with a study by Bożena Gronowska "Judicial Dialogue in the Human Rights Domain: Thoughts and Selected Dilemmas". She focuses on the broad concept of judicial dialogue, which she regards as verbal communication between various judicial authorities. ${ }^{5}$ It seems that this assumption is correct and that it reflects the sense of not just a judiciary dialogue as such but also, or maybe above all, of the dialogue taking place in the area of human rights protection. ${ }^{6}$ The author argues that this dialogue can be conducted either to resolve a controversial issue (consensual dialogue) or for the purpose of multilateral analysis of a specific legal issue (analytical-informative dialogue). The aforementioned differentiation is a very interesting analytical distinction, but it should be stressed that neither of the presented forms of the dialogue has a superior character in relation to the other form, as each of them is equally important and may result in equally significant outcomes. Securing the best possible judicial protection of human rights and freedoms is defined as the key feature of this dialogue in the human rights area. This comment is obvious but it should be noted that although it is the main goal of the judicial dialogue in the human rights area, ${ }^{7}$ other subsidiary goals are still possible as well such as, for example, increased coherence in respect to judicial assistance.

More importantly, the analytical approach presented in the study can be observed not just in the vertical plane (international courts - national courts), but also in horizontal plane both at international and national levels. It should also be highlighted that during the academic dialogue presented in the study, a proposal has been made to create a relevant forum, within which the partners of the dialogue could, in a manner most convenient for them, analyse increasingly complex interests concerning individuals in contemporary societies. This proposal is a utopian, though interesting and substantively justified,

5 Melissa Waters, "Mediating norms and identity: The role of transnational judicial dialogue in creating and enforcing international law", 93 Georgetown Law Journal (2004), pp. 487-574.

6 Ruth Ginsburg, Deborah Merritt, "Affirmative action: An international human rights dialogue”, 21 Cardozo Law Review (1999), pp. 253-260.

7 Maria-Gabriela Manea, "Human rights and the interregional dialogue between Asia and Europe: ASEAN-EU relations and ASEM", 21/3 Pacific Review (2008), pp. 369-396. 
vision of the development of the issue of judicial dialogue in the human rights area. The author also extensively discusses more extensively the role, approach and mutual relationships that occur between international courts or tribunals (horizontal relationships) as well as the position of national courts, their effectiveness and the speed of their reaction to international case law (vertical relationships). Whether it is horizontal or vertical relationships, the participants of the dialogue should always remember the key goal thereof and the main framework of international human rights protection so that the exchange of opinions is not understood as a distortion of the real dialogue by instead taking the form exclusively of a power play between various jurisdictional centres. The author's conclusion is the thesis that a reliably developed and multi-faceted judicial dialogue on human rights could constitute an element supporting the efforts to realise the idea of creating a World Human Rights Tribunal. Of course, the achievement of this goal is still an issue for the distant future. But, making every effort in favour of this utopian yet beautiful idea is a worthy cause.

In a subsequent contribution to this volume, a study by Anna Podolska "Between Informal Dialogue and Official Criticism: The Bundesverfassungsgericht, the Court of Justice of the European Union and European Court of Human Rights concerning the Protection of Human Rights and Mutual Recognition of Judgments" tackles the issue of institutional relations observed in the human rights protection area from a national perspective (the German Federal Constitutional Court) and an international perspective (the CJEU and ECHR). The area of interest is viewed through the prism of many contentious points in jurisdictional practice, which are observed particularly in the European human rights protection system (Council of Europe and European Union). This fact is not surprising as the European system contains two significant acts in the area of international human rights protection, i.e. the Convention for the Protection of Human Rights and Fundamental Freedoms ${ }^{8}$ and the Charter of Fundamental Rights of the European Union, ${ }^{9}$ and these contain a number of identical regulations. ${ }^{10}$

Each EU Member State is at the same time a Member State of the Council of Europe and additionally has its own regulations at the level of its own constitution. Consequently, this field comprises not just different decisions regarding

The Convention for the Protection of Human Rights and Fundamental Freedoms (213 UNTS 221, as amended).

9 Charter of Fundamental Rights of the European Union (OJ C 326, 26.10.2012, pp. 391-407).

10 Olivier De Schutter, "The two Europes of human rights: The emerging division of tasks between the Council of Europe and the European Union in promoting human rights in Europe", 14 Columbia Journal of European Law (2008), pp. 509-561. 
similar factual situations, but also of different interpretations of similar regulations. The activity of the countries themselves is significant and relevant also, as these countries can implement high standards of protection or understand the content of some rights in a different manner. In the author's opinion, judicial dialogue is the key to the successful functioning of the human rights protection system. This thesis is justified by quoting the respective case law of the Federal Constitutional Court, CJEU and ECHR regarding the execution of arrest warrants (for example, the issue of absolute mutual confidence generating absolute mutual recognition of the judgements) in the context of an analysis of the relationship between the mutual recognition of judgments and protection of fundamental rights.

Subsequently, the author offers the interesting argument that this form of "jurisdictional dialogue", illustrated by the cases given, does not take a form of official dialogue or direct criticism. It is instead an exchange of positions of authorities, trying to enforce their own point of view and set their own boundaries to the sharing of judgments. Unfortunately, it should be stressed that the "jurisdictional dialogue" described is not an example of a real dialogue carried out for the international protection of human rights. but is rather an example an unwillingness to cooperate. ${ }^{11}$

At the end of the study, it is noted that the diversity of the case law creates uncertainty for individuals and does not benefit the human rights protection system, whereas a properly organised judicial dialogue would be a remedy for this situation. It should be added that genuine judicial dialogue in the human rights area is focused on seeking common solutions to problems and is always ready to make concessions in the name of compromise and respect for the other party. ${ }^{12}$

The next study was written by Katarzyna Trzpis-Szysz and is entitled "Judicial Dialogue after the Genocide in Rwanda: The Example of Cooperation between International Criminal Tribunal for Rwanda and Gacaca Courts" and refers to the issue of the judicial dialogue in the human rights area observed after the civil war in Rwanda. This is an enormously interesting and original example of judicial dialogue within a specific environment, born out of conditions unfavourable to having open, substantive dialogue focused on seeking a consensus. ${ }^{13}$ First, it should be clearly accepted that judicial dialogue is

11 Anna Wierzbicka, "The concept of 'dialogue' in cross-linguistic and cross-cultural perspective", 8/5 Discourse Studies (2006), pp. 675-703.

12 Hélène Lambert, "Transnational judicial dialogue, harmonization and the common European asylum system", 58/3 International \& Comparative Law Quarterly (2009), pp. 519-543.

13 Richard Rieke, “The judicial dialogue", 5/1 Argumentation (1991), pp. 39-55. 
most often identified with cooperation between the European courts, ${ }^{14}$ but this academic study proposes to look at the aspects of this issue at the level of an international judiciary, in which third countries are involved as well. This seems to be justified by the fact that international law was developed through global dialogue and cooperation and the currently functioning human rights protection system is the result of that process. ${ }^{15}$ The author's assertion that the fundamental right to life, including the right to live in peace, is right and worthy of attention.

The introductory remarks are followed by a general outline of the conflict in Rwanda to demonstrate that these appalling events are correctly recognised as genocide. The author then outlines the first attempts to reach verdicts and the establishment of Gacaca courts. The methodological process observed in the study corresponds to the methodology of conducting academic research. It is intuitive but most importantly also logical and internally consistent. In addition, the establishment of Gacaca courts should be recognised, the author argues, as a new element of judicial dialogue. The reason for this was that the ICCR mainly prosecuted crimes by key decision-makers and public officials, while the focus of Gacaca courts' jurisdiction was on the civilian population. ${ }^{16}$ Thus, a cooperation between the aforementioned judicial authorities could be observed, which should be understood as a form of a judicial dialogue in the human rights area. The article concludes with a short summary offering interesting insights whilst setting out the scope of further deliberations, emphasising that the judicial dialogue in countries devastated by a war is extremely difficult. This is hardly surprising as in the aftermath of a civil war, a synonym of social injustice and harm, attempts to initiate any form of dialogue, not just a judicial dialogue in the human rights area, encounter barriers that are very difficult to overcome. This is because, as the author emphasises, during a civil war institutional resources are destroyed, human resources are decimated and communities are deprived of any sense of justice. It should be noted here that an efficient judicial dialogue might, should a decision to embark on such a process be taken, contribute to a quicker process of reconciliation of the warring parties to the conflict.

\footnotetext{
14 Piet Eeckhout, "Opinion 2/13 on EU accession to the ECHR and judicial dialogue: Autonomy or autarky", 38/4 Fordham International Law Journal (2015), pp. 955-992.

15 Daphne Barak-Erez, "The international law of human rights and constitutional law: A case study of an expanding dialogue", 2/4 International Journal of Constitutional Law (2004), pp. 611-632.

16 William Schabas, "Genocide trials and gacaca courts", 3/4Journal of International Criminal Justice (2005), pp. 879-895.
} 
Near its conclusion, the article notes that the judicial dialogue after the conflict in Rwanda can be considered in two ways: on the one hand at the level of subsidiary cooperation between the Gacaca courts and the public judiciary system, while on the other hand seeing Gacaca courts as an integral element of the international system of judging the crime of genocide. The specific nature of judicial dialogue in the area of international human rights protection conducted after the civil war in Rwanda is presented in that manner.

The study by Bartłomiej Oręziak entitled "Judicial Dialogue between the European Court of Human Rights and the Court of Justice of the European Union in the Field of Legal Liability for Posting Hyperlinks" reviews the highly current issue of legal liability for posting hyperlinks based on the judicial dialogue between the European Court of Human Rights and the Court of Justice of the European Union in the area of human rights protection on the internet. It should be stressed that, given the current rate of technical and social progress at present, we cannot escape issues associated with the regulation of new technologies. Disregarding or ignoring them may have serious repercussions, including consequences for the protection of human rights in the era of obvious technological revolution. ${ }^{17}$ The author's analytical approach indicates a number of limitations created by the CJEU affecting the freedom to post hyperlinks, which in turn demonstrates the scope of limitations created by that judicial authority in the copyright area. ${ }^{18}$ We should agree with the assertion that these limitations are not intuitive and do not result directly from the provisions of the EU law and are a result of extensive interpretation of intent by the CJEU, which is somewhat in conflict with the idea of the internet's purpose. Subsequently, the author considers the relationship of these limitations to ECHR case law in respect to the freedom to hold opinions, as established in Article 10 of the Convention for the Protection of Human Rights and Fundamental Freedoms in the research area. It should be emphasised that the analysis of the provisions of Article 10 of the Convention correctly compares them to ECHR limitations in the area of information technology, because the subject of these norms has high importance for freedom of expression wherever it is permitted. In no area of law is this more important than in internet regulation. ${ }^{19}$

17 Roger Brownsword, "In the year 2061: from law to technological management", 7/1 Law, Innovation and Technology (2015), pp. 1-51.

18 Ansgar Ohly, "The broad concept of 'communication to the public' in recent CJEU judgments and the liability of intermediaries: primary, secondary or unitary liability?", 13/8 Journal of Intellectual Property Law \& Practice (2018), pp. 664-675.

19 Jeremy Lipschultz, Free Expression in the Age of the Internet (2000), pp. 255-271. 
The academic problem analysed in the study concerns the consequence of substantive judicial dialogue between the CJEU and ECHR pointing out the legal-human aspects of hyperlinks on the internet. During this discussion, the key point of the analysis determines that the linguistic and functional interpretation has gone in favour of the latter court which, in author's opinion, could and even should lead to the creation of an optimum European model for the posting of hyperlinks on the internet. It should be noted that the dialogue described is not direct and rather results from the nature of the situation and legal issue requiring resolution. For the sake of clarity, it should be pointed out that the ECHR in its ruling did in fact refer to an CJEU judgment in the case of GS Media. ${ }^{20}$ It was not, however, in this case the initiator of the judicial dialogue and thus the concerned interaction could be regarded as an example of indirect judicial dialogue in the human rights area. All this may, however, contribute to further and more advanced analytical studies for the improvement of the consistency and effectiveness of international human rights protection area in the era of modern technologies. This seems a difficult, but not impossible, task facing the judicial dialogue in the human rights area.

A study by Łukasz Dawid Dąbrowski "Entitlement of Legal Entities to Hold Rights under the Inter-American Human Rights Protection System" analyses the question of whether public or private legal persons can obtain direct protection within the scope of Inter-American Human Rights System and, in the case of a positive answer, on what conditions. It should be noted that this type of issue may give rise to a wider judicial dialogue in the human rights area in the international domain because it is valid not just in the Inter-American Human Rights System, but in the European system as well. ${ }^{21}$ In this respect, the academic study focuses on the advisory opinion of the Inter-American Human Rights Court OC-22/16 adopted on 26 February 2016. ${ }^{22}$ The author in his formal analytical deliberations also concentrates on international standards regarding the rights of legal entities to apply for protection in the universal and regional human rights system. This shows the potential of judicial dialogue in the human rights area, as it could be conducted in a world-wide forum. This is because the issue at hand is a current legal problem, which can be analysed by various judicial authorities originating from different human rights protection systems. The author also studies fundamental regulations of European,

20 Judgment of the Court (Second Chamber) of 8 September 2016 GS Media BV v Sanoma Media Netherlands BV and Others, C-16o/15, ECLI:EU:C:2016:644.

21 Peter Jones, “Human Rights, Group Rights, and Peoples' Rights", in R. McCorquodale (ed.) Human Rights (2003), pp. 272-300.

22 Diego Mejía-Lemos, "Advisory Opinion OC-22/16", 111/4 American Journal of International Law (2017), pp. 1000-1006. 
African and universal human rights systems, which furthermore support the aforementioned statements. The study consists of three main parts. The first presents a very brief description of the Inter-American Human Rights System; the second part provides a brief analysis of fundamental international and regional regulations regarding human rights in the area of the rights of legal entities; while the last part concerns the advisory opinions of the Inter-American Human Rights Court adopted on 26 February 2016.

The proposed methodological layout of the study is worth noting as it suggests the high significance of the issue as a potential contribution to an already extensive international legal-human dialogue. The analysis concludes that the Inter-American system has evolved and adapted to the new challenges of our times, noting that although legal entities do not have the same rights as private individuals under the Inter-American convention, some entities - especially trade unions, tribal and native organisations and persons associated with legal entities - nevertheless have rights that result from the convention and can file petitions within the Inter-American system. ${ }^{23}$ In principle, this thesis is correct but should be complemented by an important remark: that the identified adaptation of the Inter-American system to modern times could give birth to a real dialogue in the human rights area concerning the rights of legal entities.

In summary, all of the studies presented in this issue of International Community Law Review are of a high quality and raise multiple questions of enormous interest and relevance to current issues of international law, including, above all, the issue of judicial dialogue in the human rights area. ${ }^{24}$ These studies show its potential and identify future areas that would benefit from substantive debates aimed at identifying the common features and denominators of various normative systems.

23 José de Jesús Orozco-Henríquez, "Corporate Accountability and the Inter-American Human Rights System”, 57 Harvard International Law Journal (2016), pp. 48-52.

24 Amrei Müller, Hege Elisabeth Kjos, "Introduction", in A. Müller, H. E. Kjos (eds.), Judicial Dialogue and Human Rights (2017), pp. 1-27. 